\title{
HUBUNGAN KEPUASAN PASIEN RAWAT INAP DENGAN MUTU PELAYANAN KEPERAWATAN DI KLINIK KABUPATEN JEMBER
}

\author{
Said Mardijanto, Emi Ellya Astutik, dan M. Elyas Arif Budiman \\ STIKES dr.Soebandi, Jember \\ Email korespondensi: elyasarif92@gmail.com
}

\begin{abstract}
Satisfaction with the accepted model between expectations (the standard of performance that should be) with the actual performance received by the customer, the value satisfaction felt by patients after getting health services. The quality of nursing services is the most important thing in health service agencies, to achieve the expectations and needs of customers (patients). Good quality nursing service will increase customer (patient) satisfaction. This study aims to see the relationship between patient satisfaction and quality of nursing services in clinics in Jember Regency. This type of research used in this study with a cross sectional approach. The research sample used quota sampling of 33 respondents. Chi-Square statistical test with a significance level of $\mathrm{p}<0.05$. The results showed that patient satisfaction with satisfied criteria and the quality of nursing services with good criteria. Chi-Square test resulted in a value of $p=0.020$ and a contingency coefficient of 0.374 . These results indicate that there is a weak relationship between Inpatient Satisfaction and Quality of Nursing Services in Clinics in Jember Regency. It is expected from this research that the clinic will improve the quality of nursing services to provide patient satisfaction.
\end{abstract}

Keywords: patient satisfaction, quality of nursing services

\begin{abstract}
ABSTRAK
Kepuasan merupakan model kesenjangan antara harapan (standar kinerja yang seharusnya) dengan kinerja aktual yang diterima pelanggan, kepuasan nilai subjektif yang dirasakan pasien setelah mendapatkan pelayanan kesehatan. Mutu pelayanan keperawatan merupakan hal terpenting dalam instansi jasa pelayanan kesehatan, untuk mencapai harapan dan kebutuhan pelanggan (pasien). Mutu pelayanan keperawatan yang baik akan meningkatkan kepuasan pelanggan (pasien). Penelitian ini bertujuan untuk mengetahui hubungan kepuasan pasien dengan mutu pelayanan keperawatan di klinik di Kabupaten Jember. Jenis penelitian yang digunakan dalam penelitian ini korelasi dengan pendekatan cross sectional. Sampel penelitian ini menggunakan quota sampling sebanyak 33 responden. Uji statistik Chi-Square dengan tingkat kemaknaan $p<0,05$. Hasil penelitian menunjukan bahwa kepuasan pasien dengan kriteria puas dan mutu pelayanan keperawatan dengan kriteria baik. Uji Chi-Square dihasilkan nilai $p=0,020$ dan koefisien kontingensi 0,374. Hasil ini menunjukan terdapat hubungan yang lemah Kepuasan Pasien Rawat Inap dengan Mutu Pelayanan Keperawatan di klinik di kabupaten Jember. Diharapkan dari penelitian ini agar pihak klinik meningkatkan mutu pelayanan keperawatan untuk memberikan kepuasan pasien.
\end{abstract}

Kata kunci: kepuasan pasien, mutu pelayanan keperawatan 


\section{PENDAHULUAN}

Kepuasan adalah model kesenjangan antara harapan (standar kinerja yang seharusnya) dengan kinerja aktual yang diterima pelanggan. Woodruff and Gardial dalam Supriyanto (2007). Kepuasan merupakan perasaan senang yang dirasakan oleh seseorang atas pelayanan atau produk yang diharapkan. Kepuasan menentukan keberhasilan pelayanan kesehatan.

Parasuraman (2001) dalam Nursalam (2016) mengatakan konsep kualitas layanan yang berkaitan dengan kepuasan ditentukan oleh lima unsur yang bisa dikenal dengan istilah kualitas layanan "RATER" (responsiveness, assurance, tangible, empathy dan reliability). Konsep kualitas RATER intinya adalah membentuk sikap dan perilaku dari pengembangan pelayanan untuk memberikan pelayanan yang kuat dan mendasar, agar mendapat penilaian sesuai dengan kualitas layanan yang diterima. Nursalam (2016) menyebutkan ada 12 faktor yang mempengaruhi kepuasan pasien yaitu kualitas produk atau jasa, harga, emosional, kinerja, estetika, karakteristik produk, pelayanan, lokasi, fasilitasi, komunikasi, suasana dan desain visual. Faktor yang mempengaruhi kepuasan pasien menurut Suriyanto dan Ratna (2007) adalah product quality, service quality, emotional factor, price dan cost of aquaring.

Mutu pelayanan adalah derajat memberikan pelayanan secara efisien dan efektif sesuai dengan standar profesi, standar pelayanan yang dilaksanakan secara menyeluruh sesuai dengan kebutuhan pasien (Nursalam, 2016). Pelayanan adalah pelayanan kesehatan yang terdapat di klinik. Pelayanan kesehatan bertujuan untuk mengatasi masalah kesehatan seseorang. Pasien dapat memberikan penilaian pelayanan kesehatan yang ada. Pelayanan yang sesuai harapan pasien akan menimbulkan kepuasan pasien, tetapi yang terjadi sebaliknya pasien akan kehilangan kepercayaan untuk mendapatkan jasa pelayanan kesehatan, sehingga mengurangi jumlah kunjungan pasien dan akan mengalami penurunan jumlah keuntungan yang di dapatkan di klinik. Pelayanan kesehatan merupakan bentuk jasa yang sediakan oleh puskesmas, klinik, dan rumah sakit. Salah satu bentuk layanan kesehatan di puskesmas, klinik, dan rumah sakit adalah pelayanan keperawatan. Keperawatan sebagai perangkat penting dalam pelayanan kesehatan mempunyai tanggung jawab untuk melakukan semua tindakan keperawatan dengan memberikan pelayanan sesuai standar asuhan keperawatan secara profesional. Perawat adalah seseorang yang memberikan asuhan keperawatan pada pasien selama pasien tersebut dirawat. Perawat, sebagai pemberi layanan asuhan keperawatan mulai pada tingkat rumah tangga, puskesmas, klinik maupun tingkat rumah sakit, mempunyai peran yang sangat vital. Peran perawat sangat penting karena selalu berinteraksi, berhubungan selam 24 jam dengan pasien dan mengetahui kondisi pasien selama dirawat. Mutu pelayanan berpengaruh terhadap kepuasan pasien dalam pelayanan kesehatan, karena pelayanan keperawatan menjadi penentu berkualitas tidaknya pelayanan kesehatan.

Hasil studi pendahuluan pada pasien rawat inap di Klinik X di Kabupaten Jember tanggal 28 Februari 2017 melalui wawancara 5 pasien rawat inap mengeluhkan belum puas terhadap pelayanan yang ada di klinik tersebut. Sebanyak $40 \%$ dari $100 \%$ pasien mengeluh bahwa perawat kurang tanggap atas keluhan pasien, $20 \%$ dari $100 \%$ pasien mengeluh kurangnya komunikasi perawat pada pasien, $20 \%$ dari $100 \%$ pasien mengeluh pelayanan perawat yang kurang teliti dalam melaksanakan tindakan keperawatan, dan sebanyak $40 \%$ dari $100 \%$ pasien mengeluh perawat tidak memperkenalkan diri pada pasien. Data jumlah pasien yang dirawat inap pada klinik di Kabupaten Jember setiap bulan mengalami naik turun jumlah pasien yang dirawat inap dengan jumah pasien pada bulan Oktober 100 pasien, November 102 pasien, Desember 94 pasien, Januari 128 pasien, Februari 80 pasien dan bulan April jumlah pasien sebanyak 84 pasien. Data jumlah pasien rawat inap juga dapat menggambarkan kepuasan pasien terhadap pelayanan yang diterima.

Klinik X di Kabupaten Jember mengalami penurunan dan peningkatan jumlah pasien merupakan salah satu indikasi dari ketidakpuasan pasien pada pelayanan klinik walaupun tidak signifikan dalam membuktikan kepuasan atau ketidakpuasan pasien. Klinik X di Kabupaten Jember memiliki kebijakan 
mutu dalam memberikan pelayanan prima yang berfokus pada kepuasan pelanggan, keluarga dan karyawan. Kebijakan tersebut dilaksanakan dengan cara meningkatkan kompetensi karyawan, memberikan pelayanan yang ramah, cepat, tepat dan akurat, memberikan kemudahan informasi pelayanan kepada pelanggan, menerapkan sistem manajemen mutu secara efektif dan konsisten.

Perawat dalam pelayanan kesehatan di bidang jasa yang ada klinik terhadap kepuasan atau ketidakpuasan pasien atas mutu pelayanan keperawatan. Untuk mengukur kepuasan pelayanan kesehatan penulis membuat kuesioner yang dibagikan langsung kepada pasien yang ada di klinik. Ruang lingkup penelitian ini hanya di klinik, akan tetapi sangat mempunyai potensi yang positif meliputi potensi dari tenaga medis yang profesional, manajemen yang baik, dan kualitas pelayanan yang bermutu sehingga para pasien yang melakukan kunjungan ke klinik mendapatkan kepuasan dalam pelayanan kesehatan dan meningkatkan angka kunjungan pasien.

\section{TINJAUAN LITERATUR}

\section{KEPUASAN \\ Definisi kepuasan}

Kepuasan adalah model kesenjangan antara harapan (standar kinerja yang seharusnya) dengan kinerja aktual yang diterima pelanggan Woodruff and Gardial dalam Nursalam (2016). Menurut Sabarguna (2008), kepuasan pasien merupakan nilai subjektif terhadap kualitas pelayanan yang diberikan. Menurut Nursalam (2015), kepuasan pasien berhubungan dengan mutu pelayanan rumah sakit. Dengan mengetahui tingkat kepuasan pasien, manajemen rumah sakit dapat melakukan peningkatan mutu pelayanan. Pasien yang loyal adalah "sarana promosi" yang murah. Memiliki pasien loyal akan meningkatkan daya jual institusi pelayanan kesehatan demikian juga kemampuannya untuk berlaba dengan demikian subsidi silang untuk meningkatkan kualitas pelayanan maupun imbalan yang diberikan pada seluruh SDM institusi pelayanan kesehatan tersebut juga akan dapat lebih meningkat kesejahteraannya. Gairah tenaga kerja kesehatan semakin meningkat termasuk kemampuan untuk meningkatkan kepuasan pelanggannya.

\section{Kepuasan Pelanggan (Pasien)}

Pasien adalah makhluk Bio-PsikoSosial-Ekonomi-Budaya, artinya dia memerlukan terpenuhinya kebutuhan, keinginan, dan harapan dari aspek biologis (kesehatan), aspek psikologis (kepuasan), aspek sosio-ekonomi (papan, sandang, pangan dan afiliasi sosial), dan aspek budaya. Siapa pun yang mengetahui secara khusus kebutuhan, keinginan ataupun harapan pelanggan atau pasien, maka dialah yang mempunyai keuntungan berhubungan dengan pelanggan.

Kepuasan pelanggan terjadi apabila apa yang menjadi kebutuhan, keinginan harapan pelanggan dapat dipenuhi, maka pelanggan akan puas. Kepuasan pelanggan adalah perasaan senang atau puas bahwa produk atau jasa yang diterima telah sesuai atau melebihi harapan pelanggan. Kepuasan pasien adalah karena kepuasan pasien merupakan salah indikator kualitas pelayanan yang kita berikan dan kepuasan pasien adalah suatu modal untuk mendapatkan pasien lebih banyak lagi dan untuk mendapatkan pasien yang loyal (setia). Pasien yang loyal akan menggunakan kembali pelayanan kesehatan yang sama bila mereka membutuhkan lagi. Bahkan diketahui bahwa pasien loyal akan mengajak orang lain untuk menggunakan fasilitas pelayanan kesehatan yang sama.

Pasien yang loyal adalah sarana promosi yang murah memiliki pasien loyal akan meningkatkan daya jual institusi pelayanan kesehatan demikian, juga kemampuannya untuk berlaba (profitabilitas meningkat). Dengan demikian subsidi saling untuk meningkatkan kualitas pelayanan maupun imbalan yang diberikan pada seluruh SDM di institusi pelayanan kesehatan tersebut juga akan dapat lebih meningkatkan, kesejahteraan meningkat, gairah kerja tenaga kesehatan semakin meningkat termasuk kemauan untuk meningkatkan kepuasan pelanggan. Kinerja akan semakin meningkat dimana pelayanan kepada pasien menjadi semakin baik, akibatnya pasien akan menjadi semakin puas dan bila pasien tersebut membutuhkan pelayanan kesehatan lagi dia kan menggunakan kembali pelayanan yang sama. 
Pelanggan loyal tidak sensitif terhadap tarif. Dalam jangka panjang pelanggan loyal akhirnya akan memberikan profitabilitas rumah sakit. Oleh karena itu kepuasan merupakan aset berharga. Namun, dalam upaya memuaskan pelanggan, juga harus tetap memperhatikan ukuran aspek yang lain, sehingga tidak terjadi over investment (biaya upaya memuaskan pelanggan lebih besar dari pendapatan). Figur yang menunjukkan hubungan antara kepuasan pelanggan internal dan eksternal (Nursalam, 2016).

\section{Faktor-Faktor yang Mempengaruhi Kepuasan}

Menurut Nursalam (2016), ada beberapa faktor yang mempengaruhi kepuasan pasien sebagai berikut:

a. Kualitas produk atau jasa

Pasien akan merasa puas bila hasil evaluasi mereka menunujukan bahwa produk atau jasa yang digunakan berkualitas.

\section{b. Harga}

Harga yang termasuk di dalamnya adalah harga produk atau jasa. Harga merupakan aspek penting, namun yang terpenting dalam penentuan kualitas guna mencapai kepuasan pasien, meskipun demikian elemen ini mempengaruhi pasien dari segi biaya yang dikeluarkan, biasanya semakin mahal harga perawatan maka pasien mempunyai harapan yang lebih besar.

\section{c. Emosional}

Pasien yang merasa bangga dan yakin bahwa orang lain kagum terhadap konsumen bila dalam hal ini pasien memilih institusi pelayanan kesehatan yang sudah mempunyai pandangan cenderung memiliki tingkat kepuasan yang lebih tinggi.

\section{d. Kinerja}

Wujud dari kinerja ini misalnya: kecepatan, kemudahan, dan kenyamanan bagaimana perawat dalam memberikan jasa pengobatan terutama keperawatan pada waktu penyembuhan yang relatif cepat, kemudahan dalam memenuhi kebutuhan pasien dan kenyamanan yang diberikan yaitu dengan memperhatikan kebersihan, keramahan, dan kelengkapan peralatan rumah sakit.

e. Estetika

Estetika merupakan daya tarik rumah sakit yang dapat ditangkap oleh pancaindra. Contohnya adalah keramahan perawatan dan kelengkapan peralatan rumah sakit.

f. Karakteristik produk

Produk ini merupakan kepemilikan yang bersifat fisik antara lain gedung dan dekorasi. Karakteristik produk meliputi penampilan bangunan, kebersihan dan tipe kelas kamar yang disediakan berserta kelengkapannya.

g. Pelayanan

Pelayanan keramahan petugas rumah sakit, kecepatan dalam pelayanan. Institusi pelayanan kesehatan dianggap baik apabila dalam memberikan pelayanan lebih memperhatikan kebutuhan pasien. Kepuasan muncul dari kesan pertama masuk pasien terhadap pelayanan keperawatan yang diberikan. Misalnya: pelayanan yang cepat, tanggap, dan keramahan dalam memberikan pelayanan keperawatan.

h. Lokasi

Lokasi meliputi letak kamar dan lingkungannya dan merupakan salah satu aspek yang menentukan pertimbangan dalam memilih institusi pelayanan kesehatan. Umumnya, semakin dekat lokasi dengan pusat perkotaan atau yang mudah dijangkau, mudahnya transportasi dan lingkungan yang baik akan semakin menjadi pilihan bagi pasien.

i. Fasilitas

Kelengkapan fasilitas turut menentukan penilaian kepuasan pasien, misalnya: fasilitas kesehatan baik sarana dan prasarana, tempat parkir, ruang tunggu yang nyaman dan ruang kamar rawat inap. Walaupun hak ini tidak vital menentukan penilaian kepuasan pasien, namun institusi pelayanan kesehatan perlu memberikan perhatian pada fasilitas dalam penyusunan strategi untuk menarik konsumen.

j. Komunikasi 
Komunikasi yaitu tata cara informasi yang diberikan pihak penyedia jasa dan keluhan-keluhan dari pasien. Keluhankeluhan dari pasien dengan cepat diterima oleh penyedia jasa dalam memberikan bantuan terhadap keluhan pasien.

k. Suasana

Suasana meliputi keamanan dan keakraban. Suasana yang tenang, nyaman, sejuk dan indah akan sangat mempengaruhi kepuasan pasien dalam proses penyembuhannya. Selain itu, tidak hanya bagi pasien saja yang menikmati itu akan tetapi orang lain yang berkunjung akan sangat senang dan memberikan pendapat yang positif sehingga akan terkesan bagi pengunjung institusi pelayanan kesehatan tersebut.

1. Desain visual

Desain visual meliputi dekorasi ruangan, bangunan, dan desain jalan yang tidak rumit. Tata ruang dan dekorasi ikut menentukan suatu kenyamanan.

\section{Indeks Kepuasan}

Ada beberapa faktor yang berpengaruh pada kepuasan konsumen yang secara garis besar dikategorikan dalam 5 kategori yaitu Product Quality, Service Quality, Price Emotional Factor, dan Cost of Acquiring (Supriyanto dan Ratna, 2007).

a. Product Quality

Kualitas produk adalah tentang bagaimana konsumen akan merasa puas atas produk barang dan jasa yang digunakan. Beberapa dimensi yang membentuk kualitas produk barang adalah performance, reliability, conformance, durability, feature, dan lainlain.

\section{b. Service Quality}

Kualitas layanan adalah tentang bagaimana konsumen akan puas dengan jasa yang telah dikonsumsinya. Dimensi service quality yang lebih dikenal dengan servqual meliputi 5 dimensi yaitu tangible, reliability, assurance, empathy, responsiveness. Skala nilai ditanyakan dengan skala 1-4. Skala 1 adalah tidak puas dan skala 4 adalah puas. Nilai rerata skala adalah nilai skor (skor=jumlah $\mathrm{n}$ pengukuran dikatakan skala).

c. Emotional Factor

Keyakinan dan rasa bangga terhadap produk, jasa yang digunakan dibandingkan pesaing. Emotional factor diukur dari perceived best score artinya persepsi kualitas terbaik dibandingkan pesaingnya

d. Price

Harga dari produk jasa yang di ukur dari value (nilai) manfaat dibandingkan dengan biaya yang dikeluarkan konsumen. Harga adalah harga pelayanan medis (medical care) yang harus dibayar konsumen.

\section{e. Cost of Acquiring}

Biaya yang di keluarkan untuk mendapatkan produk atau jasa.

\section{Mutu Pelayanan Keperawatan Definisi Mutu Pelayanan}

Peningkatan mutu pelayanan adalah derajat memberikan pelayanan secara efisien dan efektif sesuai dengan standar profesi, standar pelayanan yang dilaksanakan secara menyeluruh sesuai dengan kebutuhan pasien, memanfaatkan teknologi tepat guna dan hasil penelitian dalam pengembangan pelayanan kesehatan/keperawatan sehingga tercapai derajat kesehatan yang optimal. Menurut Muninjaya (2014), kualitas pelayanan kesehatan sangat ditentukan oleh kebutuhan atau ekspektasi pengguna yang sudah terpenuhi dan diterima tepat waktu.

Peningkatan kualitas pelayanan adalah salah satu isu yang sangat krusial dalam manajemen, baik dalam sektor pemerintah maupun sektor swasta. Hal ini terjadi karena di satu sisi tuntutan masyarakat terhadap perbaikan kualitas pelayanan dari tahun ke tahun menjadi semakin besar, sedangkan disisi lain, praktik penyelenggaraan pelayanan tidak mengalami perbaikan yang berani (Elisabeth dan Endang, 2015).

\section{Pengukuran Mutu Pelayanan}

Menurut Donabedian, mutu pelayanan dapat diukur dengan menggunakan tiga variabel, yaitu: input adalah segala sumber daya yang diperlukan untuk melaksanakan kegiatan seperti tenaga, dana, obat, fasilitas, teknologi, 
organisasi dan informasi. Proses adalah interaksi profesional antara pemberi pelayanan dengan konsumen (pasien dan masyarakat). Setiap tindakan medis/keperawatan harus selalu mempertimbangkan nilai yang dianut pada diri pasien. Setiap tindakan korektif dibuat meminimalkan risiko terulangnya keluhan atau ketidakpuasan pada pasien. Program keselamatan pasien bertujuan untuk meningkatkan keselamatan pasien dan meningkatkan mutu pelayanan. Interaksi profesional selalu memperhatikan asas etika terhadap pasien. Output/outcome adalah hasil pelayanan kesehatan atau pelayanan keperawatan, yaitu berupa perubahan yang terjadi pada konsumen termasuk kepuasan dari konsumen. Tanpa mengukur kinerja rumah sakit/keperawatan tidak dapat diketahui apakah input dan proses yang baik telah menghasilkan luaran yang baik.

\section{Faktor Mutu Pelayanan Keperawatan}

Beberapa aspek yang dapat menjadi indikator penerapan sebuah layanan keperawatan pada pasien menurut Marini (2010) adalah:

a. Aspek Perhatian

Aspek perhatian merupakan sikap seorang perawat dalam memberikan pelayanan keperawatan harus sabar, bersedia memberikan pertolongan kepada pasien, perawat harus peka terhadap setiap perubahan pasien dan keluhan pasien, memahami dan mengerti terhadap kecemasan dan ketakutan pasien. Perawat memperlakukan pasien dengan baik dan tulus dalam pemenuhan kebutuhannya. Perhatian yang tulus seorang perawat pada pasien harus selalu dipertahankan, seperti bersikap jujur dan terbuka serta menunjukkan perilaku yang sesuai.

\section{b. Aspek Penerimaan}

Aspek penerimaan merupakan sikap perawat yang selalu ramah dan ceria saat bersama pasien, selalu tersenyum dan menyapa semua pasien. Perawat harus menunjukkan rasa penerimaan yang baik terhadap pasien dan keluarga pasien, menerima pasien tanpa membedakan agama, status sosial, ekonomi dan budaya, golongan dan pangkat, serta suku sehingga perawat menerima pasien sebagai pribadi yang utuh. Penerimaan ialah sikap yang tidak menghakimi individu, bagaimanapun dan apa pun perilaku individu tersebut. Perawat menunjukkan sikap tegas dan jelas, tetapi tanpa amarah atau menghakimi, sehingga perawat membuat pasien merasa utuh. Perawat tidak kecewa atau tidak merespon negatif terhadap amarah yang melupakan, atau perilaku buruk pasien menunjukkan penerimaan terhadap pasien.

c. Aspek Komunikasi

Aspek komunikasi merupakan sikap perawat yang harus mampu melakukan komunikasi sebaik mungkin dengan pasien, dan keluarga pasien. Interaksi antara perawat dengan pasien atau interaksi antara perawat dengan keluarga pasien akan terjalin melalui komunikasi yang baik. Perawat menggunakan komunikasi dari awal penerimaan pasien untuk menyatu dengan pasien dan keluarga pasien. Komunikasi digunakan untuk menentukan apa yang pasien inginkan berkaitan dengan cara melakukan tindakan keperawatan. Perawat juga melakukan komunikasi dengan pasien pada akhir pelayanan keperawatan untuk menilai kemajuan dan hasil akhir pelayanan keperawatan yang telah diberikan.

\section{d. Aspek Kerjasama}

Aspek ini meliputi sikap perawat yang harus mampu melakukan kerjasama yang baik dengan pasien dan keluarga pasien. Perawat harus mampu mengupayakan agar pasien mampu bersikap kooperatif. Perawat bekerja sama secara kolaborasi dengan pasien dan keluarga dalam menganalisis situasi yang kemudian bersama-sama mengenali, memperjelas, dan menentukan masalah yang ada. Setelah masalah telah diketahui, keputusan bersama diambil untuk menentukan jenis bantuan apa yang dibutuhkan oleh pasien. Perawat juga bekerja sama secara kolaborasi dengan ahli kesehatan lain sesuai kebutuhan pasien.

\section{e. Aspek Tanggung Jawab}

Aspek ini meliputi sikap perawat yang jujur, tekun dalam tugas, mampu mencurahkan waktu dan perhatian, sportif dalam tugas, konsisten, serta tepat dalam memberikan pelayanan keperawatan. Perawat mempunyai tanggung jawab untuk memberikan pelayanan keperawatan pada pasien selama 24 jam sehari, dari penerimaan sampai pemulangan pasien. Perawat harus tahu bagaimana menjaga 
keselamatan pasien, jalin, dan pertahankan hubungan saling percaya yang baik dengan pasien, pertahankan agar pasien dan keluarga tetap mengetahui tentang diagnosis dan rencana tindakan, pencatatan semua tindakan harus dilakukan dengan akurat untuk melindungi kesejahteraan pasien.

\section{METODA}

Penelitian ini menggunakan jenis penelitian korelasional dengan pendekatan cross-sectional. Pada penelitian ini, populasi yang akan diambil adalah semua pasien rawat inap pada bulan April dengan estimasi pada bulan 84 pasien diruang rawat inap kelas II di Klinik di Kabupaten Jember. Teknik pengambilan sampel yang digunakan oleh peneliti yaitu menggunakan teknik Quota Sampling. Alat ukur yang digunakan dalam penelitian ini adalah kuesioner kepuasan dan kuesioner mutu pelayanan. Pada jenis pengukuran ini, peneliti mengumpulkan data secara formal kepada subjek untuk menjawab pertanyaan secara tertulis. Uji statistik yang digunakan adalah uji Chi-Square, Uji ChiSquare adalah salah satu uji statistik nonparametrik (distribusi dimana besaranbesaran populasi tidak diketahui) yang digunakan dalam penelitian yang menggunakan dua variabel nilai. Apabila $\alpha<0,05$, maka (H0) diterima yang bermakna ada hubungan kepuasan pasien rawat inap dengan mutu pelayanan keperawatan di klinik rawat inap di Kabupaten Jember.

\section{HASIL PENELITIAN}

\section{Kepuasan Pasien}

Kepuasan adalah model kesenjangan antara harapan (standar kinerja yang seharusnya) dengan kinerja aktual yang diterima pelanggan (Woodruff and Gardial dalam Nursalam (2016)). Kepuasan merupakan perasaan yang dirasakan oleh pasien yang telah mendapatkan pelayanan kesehatan. Pemberi pelayanan kesehatan terdiri dari dokter, perawat, bidan dan apoteker. Perawat pemberi pelayanan asuhan keperawatan selama pasien dirawat inap. Frekuensi kepuasan pasien dapat dilihat pada Tabel 1 sebagai berikut:

Tabel 1. Distribusi Frekuensi Kepuasan Pasien Bulan April-Mei 2017

\begin{tabular}{ccc}
\hline Kepuasan pasien & Skoring & Persentase (\%) \\
\hline Tidak puas & 604 & $36.6 \%$ \\
Puas & 1353 & $54.6 \%$ \\
Sangat puas & 288 & $8.72 \%$ \\
\hline
\end{tabular}

Sumber: Data diolah

Berdasarkan Tabel 1, pasien yang tidak puas terhadap pelayanan keperawatan dengan memiliki skoring 604 (36.6\%), yang puas terhadap pelayanan dengan skoring 1353 $(54.6 \%)$, dan yang sangat puas dengan skoring $288(8.72 \%)$.

\section{Mutu Pelayanan Keperawatan}

Mutu pelayanan adalah pelayanan kesehatan yang efisien dan efektif sesuai dengan standar profesi yang telah ditetapkan, standar pelayanan dilaksanakan secara menyeluruh sehingga menimbulkan pelayanan yang optimal bagi pasien. Pasien yang menerima pelayanan keperawatan tidak akan kecewa jika pelayanan keperawatan dilaksanakan sesuai standar yang ada. Frekuensi kepuasan pasien dapat dilihat pada Tabel 2 sebagai berikut:

Tabel 2. Distribusi Frekuensi berdasarkan Mutu Pelayanan Keperawatan Bulan April-Mei 2017

\begin{tabular}{ccc}
\hline Mutu Pelayanan & Skoring & Persentase (\%) \\
\hline Tidak baik & 290 & $21.96 \%$ \\
Baik & 1047 & $52.87 \%$ \\
Sangat baik & 264 & $10.1 \%$ \\
\hline
\end{tabular}


Tabel 2 di atas menunjukkan bahwa pasien yang mengatakan tidak baik atas pelayanan keperawatan dengan skoring 290 $(21.96 \%)$, pasien yang mengatakan baik pelayanan keperawatan dengan skoring 1047 $(52.87 \%)$, dan pasien yang mengatakan sangat baik atas pelayanan keperawatan dengan skoring $264(10.1 \%)$.

\section{Hubungan Kepuasan Pasien dengan Mutu Pelayanan Keperawatan}

Tabel 3. Tabulasi Silang Hubungan Kepuasan Pasien dengan Mutu Pelayanan Bulan April-Mei 2017

\begin{tabular}{ccccccc}
\hline \multirow{2}{*}{ Mutu } & \multicolumn{4}{c}{ Kepuasan } & \multirow{2}{*}{ Total } \\
\cline { 2 - 5 } & Tidak Puas & Persentase & Puas & Persentase & & $27,3 \%$ \\
Tidak baik & 0 & 0 & 9 & $27,3 \%$ & 9 & $72,7 \%$ \\
Baik & 10 & $30,3 \%$ & 14 & $42,4 \%$ & 24 & $100,0 \%$ \\
Total & 10 & $30,3 \%$ & 23 & $69,7 \%$ & 33 & \\
\hline
\end{tabular}

Sumber: Data diolah

Tabel 3 menunjukkan bahwa kepuasan pasien sebanyak 9 pasien $27,3 \%$ tetapi mutu tidak baik, responden puas sebanyak 14 pasien dan $42,4 \%$ dengan mutu yang baik, dan responden tidak puas 10 pasien $30,3 \%$ tetapi mutu baik.

Tabel 4. Distribusi Frekuensi Hubungan Kepuasan Pasien dengan Mutu Pelayanan Keperawatan Bulan April-Mei 2017

\begin{tabular}{cc}
\hline Chi Square Tests & Hasil \\
\hline$p$-value & 0.020 \\
Koefisien Kontigensi & 0.374 \\
$\mathrm{~N}$ & 33 \\
\hline
\end{tabular}

Tabel 4 menunjukkan uji hasil statistik ada hubungan antara kepuasan pasien dengan mutu pelayanan keperawatan di Ruang Rawat

\section{PEMBAHASAN}

\section{Mengidentifikasi Kepuasan Pasien}

Tabel 1 menunjukkan bahwa ada responden yang menilai kepuasan pasien dalam kategori pasien yang tidak puas terhadap pelayanan keperawatan dengan skoring 604 $(36.6 \%)$, yang puas terhadap pelayanan dengan skoring $1353(54.6 \%)$, dan yang sangat puas dengan skoring 288 (8.72\%). Menurut peneliti, indikator yang menyebabkan pasien tidak puas terhadap pelayanan keperawatan yaitu aspek kenyataan dan tanggung jawab, pada aspek kenyataan perawat masih kurang memberikan infomasi, perawat masih kurang memperhatikan ruangan rawat inap pasien, dan pada aspek tanggung jawab perawat tidak membantu dalam memperoleh obat, perawat tidak menyediakan waktu khusus untuk membantu contohnya, berjalan dan ganti posisi. Penyebab lainnya adalah bahwa terdapatnya responden yang tidak puas terhadap pelayanan keperawatan yang sudah baik dapat
Inap Klinik Nurus Syifa, Kecamatan Bangalsari, Kabupaten Jember Bulan ( $p$ value $=0.020, \alpha=0,05, \mathrm{cc}=0.374$ ).

dikarenakan tuntutan atau harapan responden yang terlalu tinggi sehingga menyebabkan pasien tidak puas sesuai dengan pendapat Woodruff and Gardial dalam Nursalam (2016). Kepuasan merupakan model kesenjangan antara harapan (standar kinerja yang seharusnya) dengan kinerja aktual yang diterima pelanggan.

Hasil penelitian di dapatkan responden yang mengatakan puas terhadap pelayanan keperawatan yang telah diterimanya dapat dilihat dari aspek keandalan, jaminan, dan empati. Menurut peneliti, perawat andal dalam mengenali masalah atau keluhan yang dirasakan pasien, perawat terampil dalam melaksanakan tindakan asuhan keperawatan dan perawat mudah ditemui bila pasien membutuhkan, sehingga menyebabkan pasien puas terhadap pelayanan keperawatan yang ada di Klinik X. Menurut Kottler dalam Asmuji (2014), tingkat kepuasan adalah perasaan senang atau kecewa seseorang yang muncul setelah membandingkan antara persepsi atau 
kesannya terhadap kinerja/hasil suatu produk dan harapan-harapannya. Kepuasan seseorang pembeli (konsumen) setelah melakukan pembelian tergantung pada kesesuaian antara prestasi dari produk yang dibeli dengan harapan dari pembeli tersebut. Pelanggan akan merasa puas jika pelayanan yang diterima minimal sama atau lebih dari yang diharapkan. Dalam hal ini, pembeli adalah pasien di Klinik X dan produk berupa jasa pelayanan keperawatan.

Menurut Parasuraman (2001) dalam Nursalam (2016), dimensi kepuasan pasien dapat dilihat dari 5 aspek yaitu, reliability (kehandalan), assurance (jaminan), tangibles (kenyataan), empathy (empati) dan responsiveness (tanggung jawab), jika 5 dimensi tersebut dapat terpenuhi maka kepuasan pasien akan meningkat. Pertama, reability (kehandalan) pasien di Klinik X dalam ketegori puas poin yang menyebabkan pasien puas yaitu perawat mampu mengenali masalah pasien, perawat tepat waktu sampai di ruangan bila pasien membutuhkan, dan perawat tentang yang dilarang dan tidak dilarang selama pasien dirawat. Kuesioner kedua assurance (jaminan) pasien di Klinik X kategori puas dikarenakan perawat perhatian terhadap keluhan pasien, perawat selalu memberikan salam dan senyum, perawat terampil dalam melaksanakan tindakan keperawatan dan perawat jujur tentang kondisi pasien. empathy (empati) responden di Klinik $\mathrm{X}$ dalam kategori puas yang menyebabkan pasien puas yaitu perawat mudah ditemui bila dibutuhkan, perawat memberikan dukungan moril, perawat sering memeriksa keadaan pasien dan perawat memberikan informasi tentang tindakan keprawatan. reliability (kehandalan), assurance (jaminan) dan empathy (empati) 3 aspek yang menunjukan pasien puas terhadap pelayanan.

\section{Mutu Pelayanan Keperawatan}

Tabel 2 menunjukan responden yang berpendapat tidak baik atas pelayanan keperawatan dengan skoring 290 (21.96\%), pasien yang mengatakan baik pelayanan keperawatan dengan skoring 1047 (52.87\%) dan pasien yang mengatakan sangat baik atas pelayanan keperawatan dengan skoring 264 (10. 1\%). Hasil penelitian ini menyimpulkan bahwa mutu pelayanan keperawatan yang ada di Klinik X dalam kategori baik, bisa dikatakan baik dapat dilihat dari aspek perhatian, aspek kerjasama, dan aspek tanggung jawab. Perawat di Klinik X sabar dalam melakukan tindakan, perawat tanggap atas keluhan pasien, tepat melakukan tindakan asuhan keperawatan dan perawat mudah dihubungi saat dibutuhkan oleh pasien. Pasien yang mengatakan tidak baik atas pelayanan keperawatan dapat dilihat dari aspek penerimaan dan komunikasi. Mutu pelayanan keperawatan yang baik akan menimbulkan kepuasan yang baik pula. Sesuai dengan pendapat Muninjaya (2014), kualitas pelayanan kesehatan sangat ditentukan oleh kebutuhan atau ekspektasi pengguna yang sudah terpenuhi dan diterima tepat waktu. Menurut Nursalam (2016), mutu pelayanan yang baik jika pelayanan keperawatan dilakukan dengan cara efisien dan efektif sesuai dengan standar profesi, standar pelayanan yang dilaksanakan secara menyeluruh sesuai dengan kebutuhan pasien, memanfaatkan teknologi tepat guna dan hasil penelitian dalam pengembangan pelayanan kesehatan/keperawatan sehingga tercapai derajat kesehatan yang optimal mengatakan. Hal ini sejalan dengan penelitian Sunarsih (2014) yang mengatakan bahwa ada hubungan positif antara kualitas pelayanan dengan kepuasan pasien.

Persepsi mutu pelayanan keperawatan ialah pelayanan yang diberikan oleh perawat terhadap pasien. Pelayanan keperawatan dilakukan secara profesional dan holistik kepada pasien yang membutuhkan perawatan yang intensif, jika pelayanan secara profesional dan holistik, maka mutu pelayanan akan baik. Mutu pelayanan di Klinik X dalam kategori baik. Faktor-faktor yang mempengaruhi mutu pelayanan keperawatan yaitu, aspek penerimaan, aspek perhatian, aspek komunikasi, aspek kerja sama dan aspek tanggung jawab yang akan diberikan oleh perawat (Marini, 2010). Aspek perhatian pasien di Klinik X dalam kategori baik mutu pelayanan keperawatan, perawat yang ada sabar dalam melakukan tindakan asuhan keperawatan, perawat tanggap atas keluhan pasien, dan perawat memperlakukan pasien dengan baik. Pertanyaan kedua tentang aspek penerimaan pasien yang mengatakan tidak baik terhadap mutu pelayanan keperawatan dikarenakan prosedur penerimaan pasien yang membingungkan dan perawat kurang, hal tersebut yang memungkinkan pasien mengatakan tidak baik mutu yang ada di Klinik 
X. Pertanyaan kuesioner aspek komunikasi pasien mengatakan tidak baik mutu pelayanan poin yang menyebabkan tidak baik mutu pelayanan keperawatan yaitu petugas administrasinya tidak memberikan informasi yang jelas kepada pasien dan petugas administrasi yang kurang memberikan informasi yang jelas, kemungkinan aspek komunikasi yang menyebabkan 9 responden di Klinik X mengatakan tidak baik dari segi mutu pelayanan keperawatan. Aspek kerjasama pasien mengatakan mutu pelayanan keperawatan di Klinik X dalam kategori baik, karena perawat yang ada dapat bekerja sama dengan baik kepada pasien, perawat tepat dalam melakukan tindakan dan perawat suportif dalam memberikan pelayanan asuhan keperawatan. Aspek tanggung jawab pada pasien di Klinik X mengatakan baik mutu pelayanan keperawatan yang ada, karena perawat dan pasien saling percaya, perawat konsisten dalam memberikan pelayanan, perawat memiliki tanggung jawab dalam memberikan pelayanan, dan perawat mampu menjaga keselamatan pasien. Kesimpulan dari mutu pelayanan keperawatan di Klinik X yang menyebabkan pelayanan keperawatan dalam kategori dapat dilihat dari aspek perhatian, aspek kerjasama dan tanggung jawab. Mutu pelayanan keperawatan tidak baik dapat dilihat dari aspek penerimaan dan aspek komunikasi.

\section{Hubungan Kepuasan Pasien dengan mutu Pelayanan Keperawatan}

Hasil uji statistik antara kepuasan pasien dengan mutu pelayanan keperawatan menunjukkan terdapat hubungan dengan nilai $p$ value $=0.02$ lebih kecil dari nilai $\alpha=0.05$ yang telah ditetapkan oleh peneliti. Pelayanan semakin puas pasien maka semakin baik mutu pelayanan keperawatan Hasil Uji Chi-Square, menyebutkan bahwa ada hubungan antara kepuasan pasien dengan mutu pelayanan keperawatan di Ruang Rawat Inap Klinik X.

Kepuasan pelanggan terjadi apabila apa yang menjadi kebutuhan, keinginan harapan pelanggan dapat dipenuhi, maka pelanggan akan puas. Kepuasan pelanggan adalah perasaan senang atau puas bahwa produk atau jasa yang diterima telah sesuai atau melebihi harapan pelanggan. Kepuasan pasien adalah karena kepuasan pasien merupakan salah indikator kualitas pelayanan yang kita berikan dan kepuasan pasien adalah suatu modal untuk mendapatkan pasien lebih banyak lagi. Pasien yang tidak puas akan mengeluhkan dan tidak akan menggunakan jasa pelayanan kesehatan yang sama. Menurut Asmuji (2014), secara umum, pengertian kepuasan konsumen atau ketidakpuasan konsumen merupakan perbedaan antara harapan dan kinerja yang dirasakan. Kepuasan konsumen berarti kinerja suatu barang/jasa sekurang-kurangnya sama dengan yang diharapkan.

Menurut peneliti, semakin tinggi tingkat kepuasan pasien maka semakin tinggi pula mutu pelayanan keperawatan yang ada Klinik $X$. Hal sesuai dengan pendapat Sabarguna (2008) bahwa kepuasan pasien merupakan nilai subjektif terhadap kualitas pelayanan yang diberikan. Menurut Nursalam (2015), kepuasan pasien berhubungan dengan mutu pelayanan rumah sakit. Dengan mengetahui tingkat kepuasan pasien, manajemen rumah sakit dapat melakukan peningkatan mutu pelayanan.

Berdasarkan hasil penelitian di Klinik X, responden mempersepsikan dalam kategori puas yaitu perawat cepat dan tanggap ketika pasien membutuhkan, pelayanan yang diterima sudah baik, perawat mampu mengenali masalah pasien, perawat terampil dalam melaksanakan asuhan keperawatan kepada pasien prosedur pelayanan yang tidak dipersulit, perawat memberikan informasi yang jelas, perawat memberikan pelayanan yang baik menunjukkan bahwa ada hubungan kepuasan pasien dengan mutu pelayanan keperawatan di Klinik X. Semakin tinggi mutu pelayanan keperawatan yang diberikan, semakin tinggi juga kepuasan pasien. Sebaliknya, semakin rendah mutu pelayanan keperawatan, maka kepuasan pasien akan buruk. Keeratan hubungan dalam kategori lemah. Oleh karena itu, klinik harus meningkatkan mutu pelayanan keperawatan agar kepuasan pasien meningkat.

\section{KESIMPULAN}

a. Mutu pelayanan keperawatan kategori puas dengan skoring 1353 (54.6\%) di Klinik X.

b. Pelayanan keperawatan di Klinik $\mathrm{X}$ dalam kategori baik dengan skoring 1047 (52.87\%)

c. Ada hubungan yang lemah ke arah positif kepuasan pasien dengan mutu pelayanan keperawatan sebesar 0,374 di Klinik X. 


\section{SARAN}

1. Bagi Klinik

Penelitian ini dapat meningkatkan daya tanggap, komunikasi, teliti dalam melakukan tindakan asuhan keperawatan, dan manajemen keperawatan yang sudah ada, sehingga pasien yang berkunjung merasa puas terhadap pelayanan keperawatan

2. Bagi akademisi

Penelitian ini dapat memperkaya perputakaan dan dapat menjadi referensi dalam menyelesaikan skripsi

3. Bagi peneliti selanjutnya

Penelitian dapat menjadi acuan bagi peneliti selanjutnya terutama terkait dengan hubungan tingkat pendidikan yang tinggi terhadap kepuasan pasien.

\section{DAFTAR PUSTAKA}

Asmuji, (2014). Manajemen Keperawatan: Konsep dan Aplikasi- Jogjakarta: ArRuzz Media.

Boy Subiro, S. 2011. Sanitasi Lingkungan dan Bangunan Kepuasan Pasien Rumah Sakit. Jakarta: Salemba Medika.

Desimawati, Wahyuni. 2013. Hubungan Layanan Keperawatan Dengan Tingkat Kepuasan Pasien Rawat Inap Di Puskesmas Sumbersari

Dian, 2013. Hubungan layanan keperawatan dengan tingkat kepuasan pasien rawat inap di puskesmas Sumbersari Kabupaten Jember. Program Studi Ilmu Keperawatan Universitas Jember

Gibson, dan Ivancevich. 2003. Organisasi, Perilaku, Struktur, Proses. Jakarta: Bina Aksara.

Hikmah, F. (2014). Kepuasan Pasien Jamsoskes terhadap Pelayanan Kesehatan di Instalansi Rawat Inap Rumah Sakit Jember Klinik dengan Metode Servqual dan Ipa. 14 (1), 1-9.

Imbalo, S \& Pohan. 2007. Jaminan Mutu Layanan Kesehatan. Jakarta: ECG

Iskandar. 2013. Keperawatan Profesional. Jakarta: In Media

Muninjaya, (2014). Manajemen mutu pelayanan kesehatan edisi 2. Jakarta Buku Kedokteran ECG
Nursalam. 2011. Manajemen Keperawatan. Aplikasi dalam Praktik Keperawatan Profesional. Edisi 3. Jakarta: Salemba Medika.

Nursalam. 2016. Manajemen Keperawatan. Aplikasi dalam Praktik Keperawatan Profesional. Edisi 5. Jakarta: Salemba Medika.

Nursalam. 2016. Metodologi Penelitian Ilmu Keperawatan. Edisi 5. Jakarta: Salemba Medika

Notoatmodjo. 2007. Promosi kesehatan dan Ilmu Perilaku. Jakarta: Rineka Cipta

Notoatmodjo. 2010. Metodologi Penelitian Kesehatan. Ed. Rev- Jakarta:Rineka Cipta.

Novi, Hervandi 2014. Hubungan Pelayanan Pasien Rawat Inap Berstatus BPJS dengan Tingkat Kepuasan Paien di Puskesmas Sumbersari Kabupaten Jember. Skripsi. Program Studi S1 Keperawatan Fakultas Ilmu Kesehatan Universitas Muhammadiyah Jember.

Parasuraman A, Zeithaml V, Berry L,. "A Conceptual Model of Service Quality and its Impact for Future Research." Journal of Marketing (musim gugur), hlm 41-50.

Petrus, (2016). Hubungan kualitas pelayanan kesehatan dengan tingkat kepuasan pasien BPJS Progam Studi S1 keperawataan STIKES Kusuma Husada Surkarta

Purwoastuti dan Walyani. 2015. Mutu Pelayanan Kesehatan dan Kebidanan. Yogyakarta: Pustaka Baru Press

Rangkut, E 2003. Konsep Pengukuran Kepuasan. Jakarta: Penerbit PT. Gramedia Pustaka Utama.

Sabarguna, B.S (a), (2008). Quality Assurance Pelayanan RS. Jakarta: Sagung Seto.

Sugiyono, (2016). Metodologi Penelitian Kuantitaif dan Kualitatif dan $R \& D$ Bandung: Alfabeta.

Sunarsih. 2014. Kualitas Pelayanan Kesehatan Dengan Tingkat Kepuasan Pasien Di Klinik Terpadu Poltekkes Kemenkes Tanjungkarang, 5(2), 121126.

Supriyanto, dan Ratna. 2007. Manajemen Mutu, Health Advocacy. Surabaya

Supriyanto S., dan M. Ernawati. 2010. Pemasaran Industri Jasa Kesehatan. 
Yogyakarta: ANDI.

Tjiptono, F.2004. Kepuasan dalam Pelayanan. Jakarta: Penerbit Salemba Empat.

Woodruff dan Gardial.2002. Practical-People Oriented Prespective. Kanada: Mc.Graw Hill, hlm 36-45.

Wijoyo dan Djoko. 2008. Manajemen Kesehatan Ibu dan Anak. Surabaya: Duta 